\title{
Gestão Sustentável Participativa Transnacional: o Direito de Acesso a Água Potável, Saneamento e sua Governança Global ${ }^{1}$
}

\author{
Transnational Participatory Sustainable \\ Management: the Right of Access to DRINKING \\ Water, Sanitation and its Global Governance
}

\section{Gestión Sostenible Participativa Transnacional: el Derecho de Acceso al Agua Potable, SANEAMIENTo y SU GobernanZa Global}

\author{
Roberto Correia da Silva Gomes Caldas* \\ Jamile Bergamaschine Mata Diz** \\ Álvaro Gonçalves Antunes Andreucci*** \\ Elizabeth Accioly****
}

1 A autora Jamile B. Mata Diz agradece o financiamento concedido pela FAPEMIG (PPM- X) para a realização da presente pesquisa.

* $\quad$ Mestre e Doutor em Direito do Estado, respectivamente em Direito Tributário e Administrativo, pela Pontifícia Universidade Católica de São Paulo (PUC-SP). Professor dos cursos de mestrado e bacharelado em Direito na Universidade Nove de Julho (UNINOVE). Professor permanente do Curso de Maestría en Derecho de las RRII y de la Integración en América Latina de la UDE - Universidad de la Empresa Montevidéu/Uruguai. External Researcher da Cátedra Jean Monnet em Direito da Universidade Federal de Minas Gerais (UFMG). Coordenador da Rede de Pesquisa "Integração, Estado e Governança". Advogado no Brasil e em Portugal. São Paulo - SP - BR. E-mail: <robertocsgcaldas@uol.com.br>. https://orcid. org/0000-0003-0772-4450

** Doutora em Direito Público/Direito Comunitário pela Universidad Alcalá de Henares - Madrid. Mestre em Direito pela UAH, Madrid Master en Instituciones y Políticas de la UE - UCJC/Madrid. Coordenadora da Cátedra Jean Monnet de Direito UFMG. Professora da Faculdade de Direito da Universidade Federal de Minas Gerais (UFMG). Professora da FDMC/MG. Coordenadora e professora do PPGD da Universidade de Itaúna. Coordenadora da Rede de Pesquisa "Integração, Estado e Governança". Belo Horizonte - MG - BR. E-mail: <jmatadiz@yahoo.com.br>.https://orcid.org/0000-0001-8709-0616

*** Doutor em História Social pela Faculdade de Filosofia, Letras e Ciências Humanas da USP, professor e pesquisador do Programa de Mestrado (Programa de Pós-Graduação em Direito - PPGD) da Universidade Nove de Julho (UNINOVE). Líder do Grupo de Pesquisa interdisciplinar entre Direito e Educação da UNINOVE, certificado no CNPq, Justiça Dialógica (GrupJus). Professor-Tutor do Programa de Educação Tutorial Administração e Direito do Ministério da Educação da Universidade Nove de Julho (PET/ADi - MEC - UNINOVE). São Paulo - SP - BR. E-mail: <andreucci@uninove.br>. https://orcid.org/0000-0003-1455-0604

**** Doutora em Direito Internacional pela Universidade de São Paulo. Professora da Universidade Europeia de Lisboa. Advogada no Brasil e em Portugal. Lisboa, Portugal. E-mail: <eaccioly@uol.com.br>.https:// orcid.org/0000-0002-1877-5109 
1 Introdução. 2 A ética do discurso quanto ao direito à água em favor de sua governança regional e global. 3 A governança do direito fundamental de acesso à água potável e ao seu saneamento: o caso brasileiro no contexto global. 4 O direito de acesso à água potável e ao seu saneamento: diretrizes de governança global segundo uma racionalidade ambiental. 5 A questão da água na Europa: o caso da Espanha e da Itália. 5.1 A Espanha e a participação comunitária. 5.2 A Itália e o bem comum. 6 Conclusão. Referências.

\title{
RESUMO
}

Atualmente, o debate sobre os usos da água, seu saneamento e gestão sustentável, tanto em âmbito nacional quanto internacional, trouxeram como pauta de relevo para os Estados, as Organizações Internacionais e as entidades privadas a necessidade de procedimentos para uma regulação concertada transnacional deste recurso natural em criação de sua global governance. Nesse sentido, dentro de uma ética discursiva do agir comunicativo, trabalhada por Habermas e Apel, a concepção da água como um direito subjetivo (direito humano fundamental) e, ao mesmo tempo, um bem comum, contribui para a superação da dicotomia clássica entre público e privado, segundo uma racionalidade ambiental em que, inclusive enquanto um dos Objetivos de Desenvolvimento Sustentável (ODSs), o seu tratamento se dá de forma concertada, (re)criando-se, assim, um novo contexto no qual tal recurso possa ser eficientemente disponibilizado e compartilhado com a humanidade.

Palavras-chave: Global Governance. Direito de Acesso à Água. Saneamento. Gestão Participativa Transnacional. Sustentabilidade.

\begin{abstract}
Currently, the debate on water use, sanitation and its sustainable management, both at the national and international levels, has brought the need for procedures for a transnational concerted regulation to the States, International Organizations and private entities in the creation of its global governance. In this sense, within a discursive ethics of communicative action worked by Habermas and Apel, the conception of water as a subjective right (fundamental human right) and, at the same time, a common good contributes to overcoming the classical dichotomy between public and private, according to an environmental rationality in which, even as one of the Sustainable Development Objectives (SDOs), its treatment takes place in a concerted way, (re)creating a new context in which such a resource can be efficiently made available and shared with mankind.

Keywords: Global Governance. Right of Access to Water. Sanitation. Transnational Participatory Management. Sustainability.
\end{abstract}




\section{RESUMEN}

Actualmente, el debate sobre los usos del agua, su saneamiento y gestión sostenible, tanto a nivel nacional como internacional, han traído como pauta importante para los Estados, las Organizaciones Internacionales y las entidades privadas, la necesidad de procedimientos para una regulación concertada transnacional de este recurso natural en la creación de su global governance. En este sentido, dentro de una ética discursiva del actuar comunicativo trabajado por Habermas y Apel, la concepción del agua como un derecho subjetivo (derecho humano fundamental) y, al mismo tiempo, un bien común, contribuye a la superación de la dicotomía clásica entre público y privado, según una racionalidad ambiental en que, incluso como uno de los Objetivos de Desarrollo Sostenible (ODSs), su tratamiento ocurre de forma concertada, (re)creándose, así, un nuevo contexto en el que tal recurso pueda ser eficientemente disponible y compartido con la humanidad.

Palabras clave: Global Governance. Derecho de Acceso al Agua. Saneamiento. Gestión Participativa Transnacional. Sostenibilidad.

\section{INTRODUÇÃO}

$\mathrm{Na}$ atualidade, as altercações em torno dos usos da água que assegurem sua disponibilidade e gestão participativa sustentável, bem como saneamento para todos, tanto em âmbito nacional quanto na União Europeia e perante a comunidade internacional, trouxeram como pauta primordial - sob um enfoque transfronteiriço para os Estados, Organizações Internacionais e entidades privadas - a necessidade de se repensar os procedimentos para uma regulação concertada transnacional dos recursos hídricos e o aprimoramento dos mecanismos de sua governança global.

Nesse sentido, dentro de uma ética discursiva trabalhada por Habermas (1989, 1997a, 1997b, 2003) e Apel (1994, 1992), a concepção concomitante da água como um direito humano fundamental e como um bem comum, em si, veio a contribuir para que seja possível superar, quanto ao tema, a dicotomia tradicional entre o que seria de interesse público e de interesse privado, de sorte a promover-se uma sinérgica relação jurídico-administrativa concertada em torno desse direito subjetivo e bem de consumo escasso (para quem pode pagá-lo ou acessá-lo), consubstanciando um dos Objetivos de Desenvolvimento Sustentável (ODSs) para se (re)pensar um novo arquétipo no qual tal recurso possa ser eficientemente disponibilizado e compartilhado com a humanidade.

Tomando como instrumento de análise a teoria do agir comunicativo e a ética do discurso habermasianas e apelsianas quanto ao contexto dialógico em que uma nova regulação global no setor de recursos hídricos deve ser discutida, lida-se com a questão da participação no contexto internacional, por parte das transnacionais (em conjunto com os demais atores envolvidos) e da global governance enquanto um conjunto de medidas regulatórias concertadas 
aplicáveis ao tema, com a tomada de decisões pelos Estados se dando no bojo de processos de integração, dentre eles o da União Europeia, cuja escolha é justificada pela preocupação externada em interagir e influenciar - ainda que principiologicamente - a criação de um adequado modelo de governança global.

Com efeito, com supedâneo na teoria do agir comunicativo, segundo a acepção de que, dentro de um processo dialógico, há que haver o respeito à opinião de todos os agentes concernidos em um debate de ideias que vise ao consenso (não obstante a possibilidade de conflitos aleatórios em seu iter), em que sua obtenção deve advir da superação do embate e do eventualmente correlato impasse, é que o direito à agua é configurado em uma tessitura concertada transnacional de integração, defluindo sua gestão sustentável e o seu respectivo controle inserido na contemporânea teoria da relação jurídica de Administração Pública, também dita relação jurídico-administrativa (WOLFF; BACHOF; STOBER, 2006).

No estudo que ora se apresenta, inclusive, o (re)pensar de um novel paradigma de governança regulatória concertada, vocacionado para o direito à água e ao seu saneamento, será inspirado a partir das experiências europeias da Espanha e Itália, consideradas pioneiras e inovadoras a ponto de permitirem a transposição dos seus aspectos mais positivos para um arquétipo de proporções globais e de cunho transnacional que possa vir a influenciar outros modelos regulatórios nacionais e/ou locais, sem olvidar, todavia, da situação do Brasil e sua respectiva regulação em igual situação, vez que a abundância de tal recurso natural em seu território, malgrado mundialmente escasso, também justifica sua análise para tal mister.

Nessa perspectiva, tem-se que o estudo deve ser dirigido para a identificação de processos de participação das comunidades e demais atores, de forma democrática e direta, que possam ser projetados e replicados especificamente para o âmbito regulatório global e internacional, superando-se, portanto, modelos de democracia meramente representativa, que segmentam, nos Estados nacionais, um sistema complexo de recursos hídricos, em olvido a uma necessária óptica globalizada, de cunho transnacional concertado e segundo a qual não existem fronteiras.

Dessa maneira, mecanismos nacionais de governança concertada compartilhados no âmbito internacional e dos distintos processos de integração regional passam a ser estratégicos para que se possa construir formas globalizadas de gestão sustentável de tal bem de uso comum, o qual, vale repisar, também se consubstancia em um direito fundamental da humanidade e em um dos ODSs, qual seja, o Objetivo 6, voltado para assegurar a disponibilidade e gestão sustentável da água e saneamento para todos (ORGANIZAÇÃO DAS NAÇÕES UNIDAS, 2015).

A metodologia de trabalho, assim, deverá centrar-se nos aspectos principais estabelecidos para uma pesquisa baseada na interdisciplinaridade do tema, ao envolver a discussão da governança regulatória concertada dos recursos hídricos, com especial foco no direito à água e seu saneamento, em um contexto de retroalimentação, partindo de exemplos nacionais que possam ser projetados e replicados em escala global (ante suas características 
transnacionais) para influenciar outros Estados, ou seja, criando-se um espaço internacional e regional de governança concertada hídrica a partir de modelos nacionais e/ou locais, com possíveis projeções e influências em outros âmbitos nacionais, maxime, e. g., em razão do incentivo governamental pátrio para a internalização e territorialização do direito à água e seu saneamento, consoante albergados nos ODSs, cujo Plano de Ação 2017-2019 (BRASIL, 2017) acaba de ser recentemente sancionado a fim de ser implementado a partir de políticas públicas nacionais, estaduais, distritais e municipais.

Nesse diapasão, a presente análise se dá consoante métodos compatibilizados com objetos que se referem a distintas áreas jurídicas e de gestão, notadamente o Direito Administrativo, Ambiental, Internacional Público e Comunitário, bem como à ciência da Administração e seu ramo público. Assim, devem-se utilizar métodos que permitam avaliar como e em que medida a aplicação de uma governança regulatória concertada de proporções transnacionais pode viabilizar um plano de ação estruturante, principalmente de políticas públicas nacionais e locais comprometidas com os ODSs, sobretudo quanto à disponibilidade e à gestão sustentável dos recursos hídricos, bem como do seu saneamento para todos, fortalecimendo, desse modo, a prosperidade, a responsabilidade socioambiental, a democracia participativa e a paz social.

A pesquisa parte, para tanto, da exposição e análise de dois casos europeus recentes sobre os usos da água - repita-se, na Espanha e Itália —, em um cotejo paralelo com o caso pátrio, utilizando-se do método dialético indutivo, segundo a técnica de abordagem bibliográfica, com o propósito de construir conceitos sobre o tema e produzir uma reflexão crítica sobre a problemática em esfera global e transnacional, a partir de um enfoque jurídico.

\section{A ÉTICA DO DISCURSO QUANTO AO DIREITO À ÁGUA EM FAVOR DE SUA GOVERNANÇA REGIONAL E GLOBAL}

A ética do discurso, quanto ao direito à água, tem sua relevância implicada com a altercação de certos pontos de ordem moral (cuja discussão necessita do envolvimento de todos os afetados), ainda mais quando aplicada à Política e ao Direito na contemporaneidade da relação jurídica de Administração Pública (também dita relação jurídico-administrativa), de modo a emprestar legitimidade, de acordo com um consenso de adequação, às respectivas políticas públicas, leis e demais normas reguladoras, assim, decorrentes do processo de debate e da justificação pública de argumentos, envolvendo a participação e a consideração das perspectivas — inclusive socioculturais — da coletividade interessada, construindo, com isso, uma governança regulatória² ${ }^{2}$ que permita uma gestão sustentável e controle eficaz.

2 A governança regulatória, aqui, externa a ideia de um método ou mecanismo de regulação de conflitos ou problemas (abarcando as atividades de gestão e respectivo controle) e, conforme explica Chevallier (2009), mediante a obtenção de soluções mutuamente satisfatórias e vinculantes aos polos de atuação, segundo negociação ou cooperação, pois que nenhum deles se revela independente o suficiente para impô-las e, também, de outro lado, para delas prescindir. 
A fim de se evitar uma governança regulatória do direito à água segmentada, coercitiva e arbitrária, afastada de uma participação ativa e isonômica dos concernidos aos conflitos que a envolvem e, assim, também afastada do almejado senso de justiça nas soluções adotadas (segundo o primado do fairness), o agir comunicativo, ramificado no discurso (habermasiano e apelsiano) embebido de uma ética universalista, formalista e cognitivista, tem na teoria social do pluralismo o instrumental indispensável para a promoção de uma governança concertada em âmbito global e de cunho transnacional, mediante uma pressuposta integração sociocultural, vista como necessária para uma democracia deliberativa fundada na cidadania participativa.

Nas palavras de Habermas (1997b, p. 86), "No seu conjunto, o mundo da vida forma uma rede de ações comunicativas. Sob o ângulo da coordenação da ação, seu componente social consiste na totalidade de relações interpessoais ordenadas legítimamente.” E, segundo as lições de Gomes e Maia (2008, p. 70), a consagração da concepção habermasiana de esfera pública "[...] se converte na ideia de 'deliberação pública' e passa a representar o ponto de partida de toda a corrente contemporânea de teoria democrática que se denomina democracia deliberativa."

Para Habermas (1997b), é importante também salientar, o Direito deve ser justificado a partir de uma moral pós-convencional de pretensão universalista, onde todos sejam incluídos de modo a construir uma dimensão deôntica do dever ser não-imposta, mas construída pelo procedimento público dialógico discursivo. $\bigcirc$ procedimentalismo, assim, registram Teixeira e Radke (2017, p. 95), "[...] é o grande eixo que liga a teoria discursiva filosófica de Habermas com o direito, uma vez que é por meio da razão comunicativa que o referido autor busca se afastar do solipsismo do sujeito." Por isso, para Apel (1992), o princípio procedimental do discurso é verificado como um critério permanente, de cunho regulatório, conservando uma validade incondicional. ${ }^{3}$

$\mathrm{O}$ agir comunicativo avulta-se, dessa forma, orientado para o entendimento mútuo, o qual ocorre, assevera Habermas (2003, p. 164-165), “[...] quando os atores tratam de harmonizar inteiramente seus planos de ação e de só perseguir suas respectivas metas sob a condição de um acordo existente ou a se negociar sobre a situação e as consequências esperadas." Segundo Apel (1992), a ética discursiva, além de fundamentar-se em princípio formal e universal (procedimento), também fundamenta-se no consenso que se vincula às relações situacionais, em direção a uma ética da responsabilidade histórica.

Dessa maneira, tendo em vista uma melhor e mais adequada gestão participativa transnacional socioculturalmente ordenada e harmonizada, isto é, integrada (e, por isso, havida por sustentável) quanto ao direito à água (tema central do estudo que ora se empreende), torna-se mister a verificação dos processos sociais para a compatibilização de sua utilização

3 Embora se conheça as divergências doutrinárias entre Habermas e Apel, as noç̃es trazidas com aporte nas pesquisas de ambos, de per si, não se revelam díspares para os fins do presente estudo, restando devidamente harmonizadas e coerentes. Com efeito, para ambos, a ética do discurso está estruturada em uma teoria da racionalidade que chamam de "razão comunicativa". 
segundo os critérios de uma racionalidade ambiental global que permita o pleno desenvolvimento dos Estados. Nos dizeres de Leff (2002, p. 126),

Para além da ecologização dos processos sociais, a resolução da problemática ambiental e a construção de uma nova racionalidade produtiva propõem a intervenção de um conjunto de processos sociais: a formação de uma consciência ecológica ou ambiental, a transformação democrática do Estado que permita e apóie a participação direta da sociedade e das comunidades na auto-gestão e co-gestão de seu patrimônio de recursos, a reorganização transsetorial da administração pública e a reelaboração interdisciplinar do saber. A gestão participativa e democrática dos recursos ambientais vai além da incorporação dos critérios de racionalidade ecológica dentro dos instrumentos da racionalidade econômica (Carrizosa, 1985), implicando a internalização dessas racionalidades 'objetivas' na racionalidade dos atores sociais que orientam o movimento ambientalista e as práticas da gestão ambiental. [...]. Assim, a dialética teórica entre lógicas opostas se traduz numa dialética social que induz transformações do conhecimento e das bases materiais dos processos produtivos. A colocação dos princípios da gestão ambiental ou a possível transição de uma racionalidade capitalista para uma racionalidade ambientalista, dá-se através de uma série de processos políticos, da confrontação de interesses opostos e o concerto de objetivos comuns de diversos setores sociais que incidem em todas as instâncias dos aparelhos do Estado (Althusser, 1970). Estes configuram o campo conflitivo da questão ambiental, que prevalece apesar do discurso ambiental que tende a dissolvê-los num consenso mundial em torno aos propósitos da 'mudança global', de 'uma só terra' e de um 'futuro comum' da humanidade (WCED, 1987).

Isso exige, segundo essa racionalidade ambiental global, que as complexas relações determinantes e de causalidade em cada um dos Estados sejam pensadas, ordenadas e harmonizadas dentro do(s) processo(s) de integração do(s) qual(is) são partícipes, de sorte que também se identifiquem os distintos elementos condicionantes que dão contorno e matizam as relações entre as suas respectivas populações, suas tecnologias e os usos culturalmente estabelecidos por si para este recurso natural em comum, em criação, pois, de uma específica governança regional, de cunho transnacional e segundo parâmetros globais, à luz de uma correlata racionalidade cultual. Segundo informa Leff (2002, p. 133-134),

A categoria de racionalidade ambiental implica a diversidade étnica. Esta se integra por diversas organizações culturais e pelas racionalidades das diferentes formações socioeconômicas que constituem uma formação nacional. A gestão ambiental implica a participação direta das comunidades na apropriação de seu patrimônio natural e cultural no aproveitamento de seus recursos. Desta forma, a racionalidade cultural não é apenas um argumento a mais da racionalidade substantiva, e sim constitui também um princípio que normatiza toda racionalidade instrumental. Os valores culturais implícitos nas práticas tradicionais de diferentes formações sociais, não só incorporam princípios de racionalidade ecológica, mas imprimem o selo da cultura na natureza através das formações ideológicas que determinam o processo de significação do meio, as formas de percepção da natureza e os usos socialmente sancionados dos recursos, vinculados a necessidades definidas culturalmente. A racionalidade cultural multiplica e diversifica as formas racionais de aproveitamento dos recursos de uma comu- 
nidade para satisfazer suas necessidades fundamentais e sua qualidade de vida. Neste sentido, a racionalidade cultural organiza e confere sua especificidade ao processo de mediação entre a sociedade e a natureza, entre as técnicas de produção e as normas de aproveitamento dos recursos naturais.

Não é por outra razão, inclusive, que por ocasião do Simpósio de Foz do Iguaçu sobre a Bacia do Prata, em 1993, defendeu-se uma bacia hidrográfica integrada, consoante noticiou Silva (2017a) ao observar que, à época, porém, tal proposta não foi bem aceita pelos Estados-membros do Mercosul, principalmente pela falta de amadurecimento das discussões neste processo de integração em torno de certas questões concernentes a ordem econômica, poluição das águas e navegação dos rios. Alertou-se, todavia, para a necessidade de se tomarem medidas a partir de estudos e experiências concretas, em prenúncio a uma governança regional que permita a gestão ambiental desenvolvimentista dessas águas de forma ordenada e harmonizada, ou seja, integrada, inclusive mediante o auxílio de peritos de diferentes áreas para a apreensão, em sua inteireza, da complexidade das relações envolvidas no processo. Nesse diapasão, Leff (2002, p. 82-83) esclarece:

[...] a gestão ambiental do desenvolvimento, fundada no potencial ecológico e na conservação da diversidade de modos culturais de aproveitamento de seus recursos, requer uma caracterização da organização específica de uma formação social. [...]. A caracterização destes processos culturais não é possível a partir da observação das práticas visíveis, nem é recuperável através de uma análise superficial de suas manifestações discursivas. Por isso é necessário pensar nas formas teóricas de articulação entre diferentes ciências e disciplinas no campo dos processos históricos, econômicos, etnológicos e ecológicos para apreender suas complexas relações de determinação e de causalidade, bem como as condicionantes que delimitam e caracterizam as relações entre uma população, sua tecnologia e o uso de seus recursos.

A integração dos processos culturais e sociais, assim, quando considerada em situações como a do exemplo acima mencionado do Mercosul em relação à gestão ambiental do desenvolvimento da Bacia do Prata, mostra-se de suma relevância a fim de que cada um dos Estados-membros tenha sua quota de participação e contribuição para a discussão em torno da exploração sustentável do potencial de suas águas.

De fato, a racionalidade ambiental para uma gestão sustentável do direito à água e seu saneamento se traduz pelo conjunto de medidas, enquanto objetivos públicos (metas ou políticas públicas), normas jurídicas e reguladoras que sejam capaz de incorporar os valores culturais de seus usos e compatibilizá-los com equidade e responsabilidade intergeracionais, de modo que, ao mesmo tempo, também viabilize sua exploração econômica mediante permissões, autorizações ou concessões estatais, inclusive a empresas transnacionais, vez ser um recurso e uma das riquezas naturais das quais os povos têm o direito soberano de gozar e usufruir livre e plenamente. Segundo Leff (2002, p. 127),

Isso conduz à construção de uma racionalidade ambiental entendida como o ordenamento de um conjunto de objetivos, explícitos e implícitos; de meios e instrumentos; de regras sociais, normas jurídicas e valores culturais; de sistemas 
de significação e de conhecimento; de teorias e conceitos; de métodos e técnicas de produção. Esta racionalidade funciona legitimando ações e estabelecendo critérios para a tomada de decisões dos agentes sociais; orienta as políticas dos governos, normatiza os processos de produção e consumo e conduz as ações e comportamentos de diferentes atores e grupos sociais, para os fins de desenvolvimento sustentável, eqüitativo e duradouro.

Com isso, é claro, não se nega a soberania permanente dos Estados para a exploração dos seus recursos e riquezas naturais, consoante previsto no art. 47 do Pacto Internacional de Direitos Civis e Políticos, apenas contextualizando-a em um cenário internacional, regionalizado e globalizado, e cujo exercício se dê mediante decisões mais sensíveis aos direitos humanos, sorvidas de uma discussão com os demais interessados e potencialmente afetados, exsurgindo, assim, como fruto de um consenso em decorrência da chamada racionalidade ambiental e da cooperação internacional inspirada pelo valor universal da solidariedade, que induz a uma gestão sustentável afinada com a equidade intergeracional. Assim entende Cançado Trindade (1994, p. 172):

Os direitos humanos se impõem e obrigam Estados, e, em igual medida, os organismos internacionais e as entidades ou grupos detentores do poder econômico, particularmente aqueles cujas decisões repercutem no quotidiano de vida de milhões de seres humanos. Os direitos humanos, em razão de sua universalidade nos planos tanto normativo quanto operacional, acarretam obrigações erga omnes.

Verifica-se, de conseguinte, à luz do direito humano fundamental da água, inserido na disciplina do Direito Ambiental Internacional, a possibilidade de se vislumbrar o início de um direito cogente vocacionando o exercício da soberania permanente para exploração dos recursos e riquezas naturais dos Estados à proteção ambiental, e, no caso, ao acesso à água potável e ao saneamento para todos, a impô-la como um dever a implicar responsabilização internacional por sua violação. Caldas e Mata Diz (2016, p 163) asseveram que

[...] pode-se já imaginar a gênese de um jus cogens no sentido de se ter, ante o dever dos Estados de proteger o meio ambiente, uma mitigação à soberania permanente sobre os recursos próprios, de sorte a impor a sua responsabilização internacional por ações omissivas e comissivas que impliquem violação a tal dever, em seu território ou no de outro Estado, em conformação ao contexto geopolítico contemporâneo. A consideração do meio ambiente como direito humano reafirma uma concepção protetiva vinculada à sua natureza de fundamental para a própria sobrevivência humana, configurando o meio ambiente sadio como uma extensão do direito à vida, portanto, considerado como cogente.

De fato, Silva (2017a), ao comentar o Princípio 21 da Declaração de Estocolmo (em 1972), que versa a respeito do direito soberano de os Estados explorarem os seus recursos segundo a sua política ambiental, menciona haver uma tendência dos Estados desenvolvidos, desde o início da década de 1990, em mitigar tal direito a favor do reconhecimento de um dever de ingerência, a ser exercido de forma individual ou coletiva (pelos próprios Estados), mediante um enforcement em caso de dano ambiental para a correlata responsabilização internacional. 
Porém, a situação concreta revela, à luz do constatado por Silva (2017b), que os danos meio ambientais (relacionados também à poluição de rios, lagos, mares e atmosfera) são advindos da atuação, principalmente, de potências industriais, surgindo, assim, sérias dúvidas quanto à possibilidade de implementação efetiva de medidas sancionatórias e coercitivas que coíbam tais condenáveis atitudes estatais. Assim, em tal contexto, o referido dever de ingerência soa muito mais como uma forma de se apenas mitigar a soberania permanente de os Estados em desenvolvimento explorarem livre e plenamente seus recursos e riquezas naturais.

Nessa perspectiva, tem-se que o estudo ora empreendido deve ser dirigido para a identificação de processos de participação das comunidades e demais atores, de forma democrática e direta, superando-se, portanto, um modelo de democracia meramente representativa, que segmenta, nos Estados, um sistema complexo de recursos hídricos, em olvido a uma necessária óptica global e transnacional concertada segundo a qual, inclusive, não existem fronteiras, e a soberania permanente sobre os recursos hídricos dos Estados seja obtemperada de acordo com uma racionalidade ambiental que vá ao encontro do que declarado pela Assembleia Geral das Nações Unidas por intermédio da sua Resolução AG 1803 (XVII), de 14 de dezembro de 1962.

\section{A GOVERNANÇA DO DIREITO FUNDAMENTAL DE ACESSO À ÁGUA POTÁVEL E AO SEU SANEAMENTO: O CASO BRASILEIRO NO CON- TEXTO GLOBAL}

Desde os anos 1970 a água se consubstancia como um dos temas de maior relevo na agenda internacional, conforme noticia Vargas (2000); começando-se pela Conferência das Nações Unidas sobre Meio Ambiente Humano, considerada como o marco da contemporaneidade do Direito Ambiental Internacional (SILVA, 2017c) (realizada em Estocolmo no ano de 1972), tem-se a Conferência do Mar del Plata, promovida pelas Nações Unidas em 1977 (na Argentina), havida como o primeiro acontecimento de cunho global e multilateral específico sobre o temário dos recursos hídricos (VARGAS, 2000), passando-se pela ECO_92, em que os recursos hídricos são um capítulo relevante da Agenda 21 nela proclamada, e pelo IV Fórum Mundial da Água, realizado na Cidade do México em 2006, onde houve o debate em torno da "Água para o Desenvolvimento, a Gestão Integrada, Saneamento, Alimentação, Meio Ambiente e a Gestão de Riscos”, até culminar na Assembleia Geral da ONU, em 28 de julho de 2010, que reconheceu, por meio da Resolução n. ${ }^{\circ}$ 64/292, a água como um direito humano.

Em verdade, diante das lições de Silva (2017c), os princípios advindos da Declaração de Estocolmo sobre o Meio Ambiente, em si, têm sido utilizados como diretrizes para programas ambientais de organizações internacionais, em especial o Programa das Nações Unidas sobre o Meio Ambiente (PNUMA), que tem dentre suas preocupações o direito à água potável e ao saneamento para todos.

Sobre a Conferência do Mar del Plata, em 1977, além de nela se ter declarado a década 
de 1980 como a "Década Internacional do Fornecimento da Água Potável e do Saneamento", vale mencionar que o seu Plano de Ação reconheceu as significativas repercussões que os projetos de desenvolvimento dos recursos hídricos têm em termos ambientais (efeitos físicos, químicos, biológicos, sanitários etc.) e socioeconômicos (ORGANIZAÇÃO DAS NAÇÕES UNIDAS, 1977).

A Conferência das Nações Unidas sobre Meio Ambiente e Desenvolvimento, celebrada no Rio de Janeiro em 1992, ante os ensinamentos de Vargas (2000), reafirmou e consagrou conceitos de crucial interesse para os países em desenvolvimento, a partir do reconhecimento do caráter multissetorial do desenvolvimento dos recursos hídricos no contexto do desenvolvimento socioeconômico e da existência de interesses múltiplos na utilização destes recursos para o abastecimento de água potável e saneamento, entre outros usos, resultando a Declaração do Rio sobre Meio Ambiente e Desenvolvimento e a Agenda 21 como um conjunto de preceitos para a conduta dos Estados e um plano de ação global para a cooperação na área ambiental.

A seu turno, o IV Fórum Mundial da Água de 2006 trouxe o vanguardista reconhecimento internacional, expresso em seu relatório final, do direito à água potável e ao saneamento básico como sendo humano fundamental (ORGANIZAÇÃO DAS NAÇÕES UNIDAS, 2006) ${ }^{5}$, o qual, segundo Sarlet e Fensterseifer (2011, p. 116-117),

[...] cumpre papel elementar não apenas para o resguardo do seu próprio âmbito de proteção e conteúdo, mas também para o gozo dos demais direitos humanos (liberais, sociais e ecológicos). Nesse sentido, a relação entre saneamento básico e proteção do ambiente resulta evidenciada, pois a ausência de redes de tratamento de esgoto resulta não apenas em violação ao direito a água potável e ao saneamento básico do indivíduo e da comunidade como um todo, mas também reflete de forma direta no direito a viver em um ambiente sadio, equilibrado e seguro.

O direito de acesso à água potável e ao saneamento básico, assim, atuam entre a garantia de um mínimo existencial de viés social (em que também se inserem moradia digna, saúde e melhoria das condições de higiene) e a proteção ambiental (vide art. $6^{\circ}, \mathrm{c} / \mathrm{c}$ art. 196 e art. 225, caput, da Constituição Federal de 1988).

Conforme salientam Costa, Mata Diz e Rezende (2015), a verificação da água como um direito humano se insere em um contexto mais amplo, no qual o próprio direito a um meio ambiente sadio e equilibrado é concebido enquanto condição prévia para o gozo dos demais direitos humanos, constituindo-se, de conseguinte, como bem observam Carvalho e Adolfo (2012), em um elemento essencial não apenas à saúde humana, mas à segurança da própria vida em sociedade.

4 Tal declaração se deu sobre a premissa de que "[...] todos os povos, quaisquer que sejam seu estágio de desenvolvimento e suas condições sociais e econômicas, têm direito ao acesso à água potável em quantidade e qualidade à altura de suas necessidades básicas." (ORGANIZAÇÃO DAS NAÇÕES UNIDAS, 1977, p. 16).

5 "A água, a essência da vida e um direito humano básico, encontra-se no cerne de uma crise diária que afecta vários milhões das pessoas mais vulneráveis do mundo - uma crise que ameaça a vida e destrói os meios de subsistência a uma escala arrasadora." (ORGANIZAÇÃO DAS NAÇÕES UNIDAS, 2006, p. 1). 
E, nesse tal contexto mais amplo acima referido, em situações de exposição do homem à poluição (da água, do ar etc.), a acepção internacional ambiental passa a ter um viés antropocêntrico imbricado, segundo um elo ululante entre saúde ambiental e saúde humana (BIRNIE; BOYLE; REDGWELL, 2009). ${ }^{6}$ A respeito, aliás, é conhecida a orientação do Tribunal Internacional de Justiça, quando do julgamento sobre o Projeto GabDikovo-Nagymaros, segundo a dicção do difundido voto do Juiz Weeramantry (1998, p. 88-89),

A proteção do meio ambiente é, da mesma forma, parte vital da doutrina contemporânea dos direitos humanos, pois é uma condição sine qua non para numerosos direitos humanos, como por exemplo, o direito à saúde e o direito à própria vida. É pouco necessário elaborar sobre isso, pois que o dano causado ao meio ambiente pode comprometer e minar todos os direitos humanos mencionados na Declaração Universal e outros instrumentos de direitos humanos. ${ }^{7}$

$\mathrm{Na}$ atualidade, ante a crescente preocupação internacional com relação à água potável e ao seu saneamento, maxime sendo ela vista como um bem de uso comum e um direito humano imprescindível à vida, a Resolução n. ${ }^{\circ}$ 64/292, de 28 de julho de 2010, da Assembleia Geral da ONU, revela-se de suma importância para que os Estados signatários desse compromisso internalizem em seus ordenamentos jurídicos o reconhecimento a tal direito, passando a regrá-lo e regulamentá-lo de forma específica, inclusive mediante a sua expressa inserção nas respectivas Constituições, de sorte a criar-se uma governança internacional e globalizada sobre tão relevante recurso e riqueza natural.

Com efeito, a Organização das Nações Unidas — ainda que para alguns com certa demora, ao reconhecer, repita-se, por meio da Resolução A/RES/64/292, de 28 de julho de 2010, o direito à água potável e ao saneamento como humano e essencial para que se possa gozar plena e amplamente a vida e todos os demais direitos humanos - impôs aos seus Estados signatários o dever de sua realização progressiva, com a obrigação de seu reconhecimento nos respectivos ordenamentos jurídicos pátrios, consoante expressamente previsto no art. 19 e art. 27 da Observação Geral n. ${ }^{\circ} 15$ de 2002. E, conforme bem lembram García López e Mata Diz (2015), o Alto Comissariado das Nações Unidas para os Direitos Humanos (2011) tem assinalado que

Aunque el derecho al agua no están reconocido expresamente como un derecho humano independiente en los tratados internacionales, las normas internacionales de derechos humanos comprenden obligaciones específicas en relación con el acceso a agua potable. Esas obligaciones exigen a los Estados que garanticen a todas las personas el acceso a una cantidad suficiente de agua potable para el uso personal y doméstico, que comprende el consumo, el saneamiento, el lavado de ropa, la preparación de alimentos y la higiene personal y doméstica (NACIONES UNIDAS, 2011, p. 3) .

6 Ver também, a respeito, Bosselmann (2015).

7 No original: The protection of the environment is likewise a vital part of contemporary human rights doctrine, for it is a sine qua non for numerous human rights such as the right to health and the right to life itself. It is scarcely necessary to elaborate on this, as damage to the environment can impair and undermine all the human rights spoken of in the Universal Declaration and other human rights instruments. 
Diante desse contexto global no qual está inserido o direito à água potável e ao saneamento básico, o Brasil, por ser signatário de tal compromisso internacional assumido perante as Nações Unidas, também externa em seu ordenamento a preocupação globalizada quanto aos usos da água que assegurem acesso, disponibilidade e gestão sustentável, bem como saneamento extensivo à totalidade da população, de sorte a permitir um consumo pessoal e doméstico de forma suficiente, saudável, aceitável e a custos módicos.

Assim, tomando-se por base o ordenamento jurídico pátrio, a Constituição Federal de 1988, ao abarcar o temário da água, o faz em outros artigos que não os destinados aos direitos e garantias fundamentais (arts. $5^{\circ}$ a 17 ), deslocando-o para o Título que considera tal recurso natural como bem da União e dos Estados, mais especificamente em seus art. 20, inciso III, e art. 26, inciso I.

Há que se mencionar existir, todavia, Proposta de Emenda Constitucional (PEC n. ${ }^{\circ}$ 39/2007) versando sobre o assunto, a qual se encontra em tramitação no Congresso Nacional, já contando com aprovação da Comissão de Constituição e Justiça da Câmara dos Deputados, desde 2014, para incluir o direito à água dentre os direitos sociais dispostos no rol do art. $6^{\circ}$, inclusive como forma de se incrementar as vias constitucionais de realização do direito fundamental à vida (art. $5^{\circ}$, caput), o direito social à saúde (art. $6^{\circ}$, caput) e à dignidade humana, esta enquanto fundamento da República Federativa (art. $1^{\circ}$, III).

Em âmbito infraconstitucional, a Política Nacional de Recursos Hídricos foi instituída pela Lei n. ${ }^{\circ}$ 9.433/97 (BRASIL, 1997), reconhecendo expresamente, em seu art. $1^{\circ}$, I e II, que a água é um bem de domínio público e um recurso natural limitado, dotado de valor econômico. A referida Lei, vale mencionar, cria o Sistema Nacional de Gerenciamento de Recursos Hídricos, trazendo elementos inovadores em comparação à legislação até então vigente, o Código de Águas de 1934, ao estabelecer um novo referencial mediante a previsão de sua gestão integrada, descentralizada e participativa em todos os âmbitos federativos da Administração Pública (art. $3^{\circ}$, I a VI), buscando dar-lhes um uso e destinação sustentáveis.

Tal legislação, de fato, trata da água como um valor econômico e também socioambiental, expressando grande mudança quanto à consideração de seus usos múltiplos e prioridades, à sua finitude e à participação popular e controle social na sua gestão sustentável, segundo uma exploração dos recursos hídricos capaz de gerar riquezas com o menor impacto ambiental para gerações presentes e futuras, inclusive mediante apenação e responsabilização pelas perdas e danos causados no uso irregular.

Dentro de um modelo de gestão sustentável dos recursos hídricos idealizado pelas Nações Unidas, em que o foco primordial é o bem-estar humano e a integridade dos ecossistemas, com a disponibilização e o abastecimento da água e seu saneamento universalizado ocorrendo de forma suficiente e segura para atender às necessidades básicas de todas as pessoas, mediante serviços confiáveis e acessíveis, o paradigma brasileiro traz em contribuição a previsão de um sistema de informações sobre recursos hídricos centralizado e transparente, de sorte a permitir que tal gestão sustentável se revele efetiva- 
mente concertada, trazendo maior racionalidade quanto ao planejamento estratégico de sua utilização e correlata outorga (de uso) ao setor privado, mediante uma classificação dos corpos d'águas mais consentânea com suas destinações mais preponderantes, além de garantir real modicidade das tarifas respectivas.

São tais pontos positivos que merecem ser replicados em escala mundial, em um modelo de global governance que cada vez mais vem se aprimorando a partir não apenas de estudos, mas de experiências nacionais bem-sucedidas, inclusive a investir mais na gestão participativa e menos na privatização desse recurso. Conforme salientou Heller (2018, online) ao se referir à privatização dos serviços voltados para o saneamento básico, "É necessário, quando se pensa em soluções como essa, aprender com a experiência de outros países e com estudos acadêmicos que avaliaram os processos de privatização. Há que se ter cuidado."

A crítica mais contundente, contudo, é relacionada à ausência de uma visão da água enquanto direito humano, consoante internacionalmente reconhecido, vez que, além de não encerrar uma previsão a respeito de seu cunho fundamental, a Lei n. ${ }^{0}$ 9.433/97 (BRASIL, 1997) estabeleceu que sua priorização para o consumo humano dá-se tão só em caso de escassez.

Com isso, não obstante os esforços internacionais, a legislação pátria se revela defasada e com uma visão mercantilista quanto ao uso da água, dissentindo do próprio equilíbrio decorrente do tripé da sustentabilidade haurido de uma interpretação sistemática da Constituição Federal de 1988 (art. 170, caput, c/c art. 193 e art. 225, caput), em contrariedade inaceitável.

E tal crítica se reforça ao verificar-se o tratamento dispensado à água pelo Código Civil de 2002, pois em seu art. 1.228, $\S 1^{\circ}$, embora haja um reconhecimento expresso do seu valor econômico e socioambiental, a sua fundamentalidade enquanto um direito humano tem que ser haurida a partir de uma interpretação sistemática e extensiva, passando pela sua categorização como um direito público (rios e mares), enquanto bem de uso comum do povo (art. 99, I) e, em seguida, como um direito privado, decorrente quer de uma óptica marcadamente particular — como no caso de álveo abandonado (art.1.252) —, quer de uma dimensão mais coletiva - como no caso do direito de vizinhança e de construir, e sobre o condomínio edilício e laje (art.1.288 a art.1.296; art. 1.300, art. 1.309 e art. 1.310; art. $1.331, \S 2^{\circ}$, e art. 1.510-C, $\S 1^{\circ}$, III).

Quanto ao saneamento básico, a par de poder ser considerado como uma modalidade de controle de fatores decorrentes do meio humano - os quais implicam, ou podem implicar, nocividade ao bem-estar físico, mental e social —, acaba consubstanciando-se em um conjunto de medidas, serviços, infraestruturas e instalações operacionais voltados a abastecimento de água potável, esgotamento sanitário, limpeza urbana e manejo de resíduos sólidos, além de drenagem e manejo das águas pluviais urbanas, com vistas à melhora da vida e da salubridade da população nas esferas federal, estadual, distrital e municipal, sendo tal concepção prevista pelo art. $2^{\circ}$, caput e inciso I, letras "a" a "d", da Lei Federal 
n. ${ }^{\circ} 11.445 / 07$, ao estabelecer as diretrizes nacionais e a política federal de sua gestão.

Nesse contexto, o Munícipio é responsável pelo planejamento do saneamento básico, porquanto tema de interesse local (art. 30, I e V, da Constituição Federal de 1988), com a prestação dos serviços podendo ser feita em parceria com o setor privado. Tais serviços, vale ressaltar, têm sua execução geralmente bastante prejudicada em função da tradicional falta de recursos na esfera local (municipal) e dos consabidos desvios de recursos advindos de outras esferas federativas, a explicar, assim, a hodierna precariedade da rede de saneamento básico brasileira.

O paradigma regulatório pátrio para o saneamento e sua universalização tem pontos positivos realçados pelas Nações Unidas:

O marco regulatório é muito importante. É necessário, mas não é suficiente. [...]. Ele prevê o planejamento como eixo central, menciona o controle social, o respeito ao direito dos titulares dos serviços. Fala em proteger as populações de baixa renda, entre outros aspectos. (HELLER, 2018, online).

Com efeito, Heller (2018) elogiou a regulação brasileira para o saneamento básico, criada em 2007 e considerada como algo positivo e vanguardista. No entanto, ressalvou que a legislação não se transformou em medidas efetivas que permitissem acesso da população a esses direitos,

Mas, evidentemente, existe um 'gap' entre se aprovar a lei e implementá-la... Esse marco regulatório, em conjunto com mais financiamento que ocorreu até o final da década de 2000 , foi muito positivo. Isso aumentou em alguma medida a cobertura. Mas, ainda há muito que fazer (HELLER, 2018, online).

A crítica maior é relacionada à falta de investimentos estruturais, em gestão, tarifação módica e planejamento, demonstrando inexistir no Plano Nacional de Saneamento uma prioridade governamental hodierna, o que se reflete em médio e longo prazos.

Não tem havido algo que o Plano Nacional de Saneamento aponta como fundamental, que é investir em medidas estruturantes, como fortalecer a gestão, pensar em bons modelos tarifários, investir no planejamento, na regulação... Esse ambiente institucional é tão importante e talvez até mais do que dinheiro, financiamento. E na minha percepção isso tem sido deixado de lado nos últimos anos (HELLER, 2018, online).

Pelo que se pode observar, a Organização das Nações Unidas tem desvelado seguidos esforços para que o acesso a água potável e saneamento universal sejam concebidos enquanto direitos fundamentais, mediante a adoção de medidas para, e. g., declarar-se o lapso compreendido entre 2005 e 2015 como a "Década Internacional para a Ação Água para a Vida", em paralelo aos Objetivos de Desenvolvimento do Milênio (ODMs) e, na sequência, ter-se incluído tal previsão quanto à água e ao seu saneamento dentre um dos hodiernos Objetivos de Desenvolvimento Sustentáveis (ODSs), qual seja, o Objetivo 6 que visa assegurar a disponibilidade e gestão sustentável da água e saneamento para todos (ORGANIZAÇÃO DAS NAÇÕES UNIDAS, 2015), enfatizando sobremaneira a preocupação em torno dos 
recurso hídricos e sua escassez crescente, impondo aos Estados um posicionamento mais ativo e efetivo.

Por fim, cumpre se exaltar a preocupação com uma tendência de privatização de tais serviços e dos recursos hídricos de modo geral, quer em âmbito nacional ou internacional, porquanto, embora tal inclinação privatista não prejudique diretamente os direitos humanos em si, implica risco de aprofundamento das desigualdades sociais, ante a pungência que apresenta para a mitigação dos controles (estatais e sociais) em favorecimento à cobrança de tarifas elevadas e à formação de oligopólios que açambarquem suas vias de acesso e universalização, em seu defeso rateio.

O domínio público sobre as águas potáveis e o saneamento, em si, revela-se como uma medida estratégica tanto econômica quanto de características geopolíticas, vez que, em um futuro não tão longínquo, a água potável e os seus respectivos corpos serão um dos bens mais preciosos e escassos do planeta, segundo uma visão que toma por base as circunstâncias atuais em que tal recurso natural se apresenta gerido.

Dessa maneira, a eventualidade de uma privatização dos recursos hídricos de forma alguma poderá prescindir tanto de uma regulação estatal de mercado, como também de seu viés concertado, a implicar a participação ativa da população, inclusive acompanhando a fiscalização dos serviços para que não haja violação aos direitos humanos diretamente implicados. Nesse diapasão tem-se:

[...] a sociedade precisa regular o Mercado para garantir a sobrevivência de todos e, por isso mesmo, apenas pode se supor um procedimento racional porque o contrato social, que permitiria o respeito aos direitos básicos das pessoas, é celebrado entre sujeitos racionais que têm em comum mundos da vida cotidianos (IULIANELLI, 2003, p. 35).

No mesmo sentir destas ideias, Heller (2018, online). asseverou, em consonância com a racionalidade ambiental aplicável à espécie, que "Se a privatização se dá sem uma regulação minimamente relevante, pode levar a violações dos direitos humanos, claramente, a aumento de tarifas, exclusão de populações de baixa renda, exclusão das populações rurais."

\section{O DIREITO DE ACESSO À ÁGUA POTÁVEL E AO SEU SANEAMENTO: DIRETRIZES DE GOVERNANÇA GLOBAL SEGUNDO UMA RACIONALI- DADE AMBIENTAL ${ }^{8}$}

E, por se referir à possibilidade de privatização da gestão dos recursos hídricos e dos serviços a eles correlatos, é preciso se ter na retentiva a observação trazida por Heller ao afirmar que a inclinação mundial não é neste sentido, havendo uma reestatização dos serviços privatizados neste setor: "Há estudos que mostram que nos últimos 15 anos ocorreram

8 As ideias contidas neste tópico se verificam anteriormente tratadas, de forma isolada, em Andreucci e Caldas (2018), sendo ora apresentadas com acréscimos, revisões e modificações. 
quase 250 remunicipalizações em várias partes do mundo, por diferentes insatisfações com o prestador privado." (HELLER, 2018, online).

Dessa forma, diferentemente da diretriz que incentiva a privatização da gestão dos recursos hídricos, entende-se que é importante, seguindo-se a tendência global, compreender que a água deve ser caracterizada como um bem difuso de uso comum e, por essa razão, sujeita a uma governança publicizada, local, democrática, participativa e, ainda, guardando uma perspectiva inter e transnacional

Em linhas gerais, os bens comuns são entendidos, contemporaneamente, como aqueles que não foram apropriados juridicamente, quer seja por parte de particulares, quer seja por parte do Estado. Dessa forma, não se encaixam na dicotomia clássica entre direito público e direito privado, que, há séculos, rege (ainda que, hodiernamente, de forma mais atenuada) as Ciências Jurídicas e Sociais. Logo, especificamente, não se referem a um ou outro (público ou privado), pois suas características naturais ou suas funções ecológicas impossibilitam-nos de assim serem classificados, mesmo que, em algumas situações, suas propriedades possam aparentar ser ou até corresponder a algumas delas (CORTE, 2015, p. 261).

Sendo caracterizada como um bem difuso de uso comum, a água, assim, distancia-se de uma abordagem meramente mercantilista, predatória e, de conseguinte, de uma gestão e titularidade privatizadas, aproximando-se da comunidade à qual pertence e interage como um recurso natural, riqueza e meio físico, mediante uma visão estratégica e uma racionalidade ambiental que tenham por base a concertação. Conforme explicita Corte (2015, p. 259-262):

Os objetivos, as estratégias e os impactos das lutas pela justiça na questão da água ligam-se à governança local, regional, nacional e internacional hídrica, ao demandarem por maior participação social, por se manifestarem pela publicização da gestão, por requererem a inserção de temas, para além de questões técnicas e administrativas, na elaboração e na execução de leis e políticas, por buscarem o reconhecimento do direito à água como um bem comum, entre outros. No passado, o espaço democrático para participação na tomada de decisões, para o debate e, quando possível, para a solução de conflitos, entre outros, era inexistente... Como alternativa ao dualismo (público versus privado), deve-se ponderar outras formas de gestão que mesclem, que substituam ou que utilizem, de maneira aperfeiçoada, instrumentos clássicos das instituições estatais e dos mecanismos privados. Há dificuldades de se reconhecer outras opções, com base em epistemologias distantes [...] pois há um pensamento dominante, hegemônico, monocultural já sedimentado.

Adotando uma crítica alinhada a uma perspectiva de governança contra-hegemônica que se oponha aos propósitos neoliberais (no mais das vezes, de privilégios), sendo estes caracterizados por padrões internacionais ${ }^{9}$ como, e. g., os descritos nos guias de boa governança do Fundo Monetário Internacional (2007) e do Banco Mundial (1992, 2011), percebe-se

9 Padrões os quais, calha explicitar, relegam a segundo plano os imperiosos fatores políticos, econômicos, ambientais e culturais regionais em sua integralidade, maxime ao imporem uma paz governança preordenada e estabelecida mediante um arquétipo aplicado de forma geral e indiscriminada, de sorte a restar, assim, carente de legitimidade e, por isso, destinada ao malogro em locais de pós-conflito (RICHMOND, 2010). 
que o contexto proposto por uma governança internacional globalizada dos bens naturais precisa levar em conta a complexidade de situações particulares e das identidades culturais, econômicas, políticas e ambientais como artífices de uma gestão comunitária. Importante, com isso, considerar a descentralização administrativa para a implementação da participação comunitária.

A governança passa a utilizar espaços e estratégias locais de aliança e cooperação, sendo que, quando bem-sucedidas, estas acabam sendo replicadas no âmbito internacional, num sistema de cooperação mútua sob a influência da solidariedade em suas distintas vertentes (dependendo da classificação, podendo ser nacional, internacional e econômica (PUY MUÑOZ, 1983), ou interterritorial, econômica e intergeracional - (GARCÍA LÓPEZ; MATA DIZ, 2015).

Quando se pensa na dimensão de uma governança internacional e globalizada, é necessário aludir a quais critérios serão utilizados para balizar e fundamentar uma ética comum. Nesse sentido, é preciso conceber-se a ideia de socialização do risco (BECK, 1998), de modo que a sociedade possa solidarizar-se com a circunstância de que não é mais possível se pensar apenas em uma responsabilização individual a posteriori (segundo uma lógica pura de culpa), como nos casos de desastres ambientais, mas sim, à luz do primado da precaução, ter-se uma previsão desse risco de forma coletivizada e, portanto, de responsabilidade mútua, segundo uma dimensão social (CALDAS; MATA DIZ, 2018). Nesse diapasão,

Fundamental neste debate é apontar para a ideia de que, ultrapassados os exageros, seria possível encontrar um caminho mais equilibrado, onde a imputação de responsabilidade fosse dissociada da reinvindicação de indenização, levando 'de uma gestão individual da culpa para uma gestão socializada do risco’. (ANDREUCCI, 2013, p. 240).

Esse modelo de socialização do risco fica mais claro, vale mencionar, quando transposto para uma realidade de relações em escala internacional, em auxílio a estratégias de governança global e de políticas transnacionais que tratam dos recursos hídricos fundamentais à manutenção da vida.

É nessa linha que Dardot e Laval (2017) lidam com a possibilidade de o princípio do comum (no caso específico, voltado para a água enquanto bem difuso de uso comum, gerido em parceria com as comunidades pelos órgãos públicos locais) se tornar um eixo do Direito, na dimensão mundial, sendo capaz de impor-se aos diversos Estados e estruturar a ação das suas instituições; a resposta implica descobrir como coordenar os comuns sem que, com isso, o seu autogoverno seja questionado.

Os autores propõem a ideia do surgimento de um novo sujeito do Direito mundial, qual seja, a própria humanidade, "[...] por uma espécie de retroação simbólica dos direitos fundamentais que lhe são atribuídos em tratados, pactos e convenções." (DARDOT; LAVAL, 2017, p. 561).

Porém, na análise desses pensadores, existem diversos obstáculos, como o princípio da soberania e a incessante busca por estratégias de concorrência predatória do capitalismo, os quais acabam por reverberar nos diversos sistemas de Justiça que, na nomenclatura dos 
autores, instituiu um verdadeiro "fórum shopping", ou um "mercado de jurisdições", beneficiando empresas transnacionais que possuem grande mobilidade no cenário internacional e que podem escolher livremente as normas que mais lhes convêm

\begin{abstract}
A 'evasão judicial' por meio do 'mercado de jurisdições' (fórum shopping) é tão sistemática quanto a evasão fiscal. Os poderes econômicos privados, por ação da concorrência, tornam-se fonte direta das normas comerciais, econômicas e, portanto, sociais. Entende-se então por que a lex mercatória está muito mais avançada do que o direito que visa à proteção das pessoas em nível internacional. O tempo do comércio é mais rápido que o tempo dos direitos, porque o próprio direito tornou-se um bem de comércio. Em matéria de saúde, cultura, acesso à água e poluição, a lógica que se impõe é a do livre-câmbio e do respeito absoluto aos direitos de propriedade. A OMC e seu órgão de Solução de Controvérsias (OSC) tem como principal objetivo a interiorização da norma internacional neoliberal em cada um dos Estados nacionais. Quanto mais eles aceleram a internacionalização do direito comercial, mais freiam a ampliação dos direitos humanos (DARDOT; LAVAL, 2017, p. 564).
\end{abstract}

Segundo os autores (DARDOT; LAVAL, 2017), esse movimento caracteriza-se por configurar uma "privatização do direito internacional" em prol dos interesses privados, o que entra frontalmente em choque com a proposta de se construir uma revalorização da participação comunitária na gestão desses bens difusos de uso comum, o que implicaria considerar uma solidariedade no risco quando da construção de princípios para um sistema de governança internacional globalizada, relativo aos bens fundamentais à manutenção da vida.

Observa-se, dessa forma, ante tais reflexões, algumas das dificuldades epistemológicas e práticas que aqueles que estão envolvidos em construir e consolidar sistemas de proteção internacional, na conjuntura global, enfrentam para com a preservação, manutenção e ampliação de qualidade da vida humana na Terra, haja vista, nessa perspectiva, bens difusos de uso comum como a água, também considerada como um direito humano fundamental em tal equação.

Cabe, outrossim, salientar que no âmbito das relações internacionais, caracterizadas apenas pela presença de Estados em uma situação isonômica de não possuírem uma autoridade superior, a denominada anarquia (ou, como também dito, sistema anárquico nas relações internacionais) exsurge com a possibilidade de se introduzir novos arranjos e relações com novos atores advindos da sociedade que permitam se contornar obstáculos tradicionais a prol de uma global governance concertada.

Assim, segundo essa concepção de ausência de poder superior no âmbito das relações internacionais é que se proporciona uma situação de possível (co)criação dos arranjos a serem instituídos entre os participantes (Estados entre si e com representantes do setor privado), mediante uma responsabilização coletiva desse arranjo (e de seus riscos inerentes) e uma cooperação mútua.

Nessa linha de argumentação, Gonçalves e Costa asseveram, em trabalho sobre os regimes internacionais, que a cooperação e a anarquia podem ser importantes estratégias 
para que se construam laços concertados que minimizem os riscos no âmbito das relações internacionais e, portanto, na formação de estratégias de governança global:

Aliás, as próprias ações de governança global se beneficiam dos instrumentos oferecidos pela teoria dos regimes internacionais e que auxiliam a construção concreta de mecanismos regulatórios internacionais, intensificando a cooperação e facilitando a criação de mecanismos que tornam as instituições e organizações permeáveis a instrumentos de democracia participativa. Isso, ao que parece, é o mais importante (GONÇALVES; COSTA, 2011, p. 216) .

Para os autores, a cooperação, num contexto de anarquia, independe da institucionalização, podendo "[...] emergir de maneira espontânea, da consolidação de regularidades comportamentais mutuamente reforçadas pelos atores, sem a necessidade de qualquer ajuste formal ou elaboração normativa." (GONÇALVES; COSTA, 2011, p. 155).

De tal sorte, diferenciando-se a cooperação anárquica acima descrita de uma institucionalizada, tem-se que a anarquia, no sentido de ausência de um poder superior, pode ser interpretada de modo a possibilitar arranjos internacionais concertados que enfrentem tendências hegemônicas de uma globalização predatória promovida por empresas transnacionais, fortalecendo, assim, democracias participativas a partir de deliberações junto a comunidades locais.

\section{A QUESTÃO DA ÁGUA NA EUROPA: O CASO DA ESPANHA E DA ITÁLIA ${ }^{10}$}

Conforme noticia Accioly, se nos primórdios da União Europeia não existia uma preocupação com a questão ambiental, ao longo de seu processo evolutivo a necessidade de medidas protetivas dessa natureza despontam com intensidade, culminando em seu papel protagonista no cenário internacional sobre esta temática:

Lembre-se que o Tratado de Roma, assinado em 25.03.1957, não tinha preocupações com o meio ambiente. Não havia em seus dispositivos nenhuma norma que tratasse de questões relacionadas com a proteção ambiental, isso porque naquela época pouco ou quase nada existia nesta área [...] houve uma forte vontade política por parte dos Estados membros em preservar e proteger o meio ambiente no quadro comunitário na primeira revisão do Tratado da CEE, com o Ato Único Europeu, em 1986, que tinha por objetivo preservar, proteger e melhorar a qualidade do ambiente; contribuir para a proteção da saúde das pessoas; e assegurar uma utilização prudente e racional dos recursos naturais [...]. O Tratado da União Europeia, de 7.02.1992, insere um novo objetivo, que traduz a importância da União Europeia na cena internacional, qual seja: promover, no plano internacional, medidas destinadas a enfrentar os problemas regionais ou mundiais do ambiente (ACCIOLY, 2000, p. 72-74)

A água, com sua definição de um bem difuso de uso comum para atendimento às necessidades básicas do ser humano, ganhou, como visto nas lutas políticas pela defesa de

10 As ideias contidas neste tópico se verificam anteriormente tratadas, de forma isolada, em Andreucci e Caldas (2018), sendo ora apresentadas com acréscimos, revisões e modificações. 
sua potabilidade e saneamento, e. g., na Espanha e na Itália, uma nova acepção, de sorte a galgar também o status de um direito humano fundamental.

Mesmo com o reconhecimento de ser um direito humano pelas Nações Unidas, em eventos ${ }^{11}$ e em resoluções, o que se caracterizou como um avanço simbólico e significativo, a privatização da água encerra a preocupação com diferentes interesses envolvidos e as diversidades entre posições concernentes, divergentes e até mesmo antagônicas quanto a certos aspectos, conforme existentes no cenário internacional.

Em uma ampla pesquisa sobre a governança global, realizada ao longo de dez anos e concluída em 2012, Biermann e Pattberg (2012) chegaram à conclusão, dentre outras, da necessidade de se construir uma integração co-evolutiva entre, no âmbito internacional/ regional, as políticas sobre biodiversidade e, no âmbito interno dos Estados-membros da União Europeia, as políticas de produção, proteção e gestão dos recursos naturais

No geral, nossa pesquisa indica que a integração da UE é uma força motriz importante por trás das mudanças das políticas de biodiversidade nos novos estados membros da UE. A co-evolução bem-sucedida de novas instituições políticas e econômicas no nível regional com instituições nacionais existentes para proteção da biodiversidade é uma condição básica para a consolidação institucional (BIERMANN; PATTBERG, 2012, p. 230). ${ }^{12}$

É nessa senda que a União Europeia, com sua governança regional, busca influenciar a governança global, identificando princípios comuns e universais para que possa ocorrer harmonização e ordenação entre os distintos processos de integração, inclusive em torno de certas questões de cunho ambiental, como, in casu, o direito de acesso à água potável e ao seu saneamento universal. Conforme constatam Caldas, Mata Diz e Carvalho (2018, p. 224):

Em seu Livro Branco, a Comissão ressalta o papel da 'coerência política global', enfatizando a necessidade de haver uma abordagem do impacto territorial das políticas da União Europeia em áreas como transportes, energia e meio-ambiente, sem, no entanto, utilizar uma lógica demasiadamente setorial (2001). [...]. A tal efeito, após a publicação do Livro Branco, a União Europeia emitiu um 'Relatório da Comissão sobre a Governança Europeia', em 2002, e publicou uma 'Comunicação da Comissão ao Conselho, ao Parlamento Europeu e ao Comitê Econômico e Social Europeu', com o título 'Governança e desenvolvimento', em 2003. [...]. A União Europeia deseja que os Estados-membros consigam promover os objetivos de paz, crescimento, emprego e justiça social não só dentro de seus territórios, mas também de forma global. Para atingir tal objetivo, os Estados da União deverão mostrar-se acessíveis a intervenções de governos e entes não governamentais extrabloco, levando em consideração a dimensão global que suas políticas podem tomar ao apreciar o impacto destas. Ademais, o Livro Branco (Comissão Europeia, 2001) ressalta o papel que a União deve

11 Para uma análise sobre os Fóruns Mundiais da Água, vide: Zorzi, Turatti e Mazzarino (2016).

12 No original: "Overall, our research indicates that the EU integration is an important driving force behind changes of biodiversity policies in the new EU member states. The successful coevolution of new political and economic institutions at the regional level with existing domestic institutions for biodiversity protection is a primary condition for institutional consolidation". 
exercer nas negociações multilaterais, buscando sempre ampliar a observância da boa governança e a melhora da eficácia e da legitimidade no processo global de decisão. A Comissão Europeia prevê que muitas das ideias apresentadas no Livro Branco (2001) podem ser aplicadas de forma global, como o desenvolvimento de soluções co-regulamentares e o controle colegiado dos progressos alcançados na persecução dos objetivos acordados. Dessa forma, pode-se notar que a União Europeia reconhece, em um de seus documentos mais importantes, a crescente interface entre a governança europeia e a governança global.

No mundo atual nos deparamos com diversas dificuldades relativas ao gerenciamento dos recursos naturais que apresentam uma interrelação e uma interdependência entre as dimensões macro e microscópica. Para além das diversas definições - e implicações que estas definições proporcionam - , a globalização é um termo que demonstra a dimensão macroscópica da atuação humana no planeta Terra, sendo mensurável e causadora de consequências.

Toda ação que implica a manutenção da vida humana tem uma óbvia importância naquilo que diz respeito aos modelos de seu uso e previsão (nos curto, médio e longo prazos) de atividades (e impactos) que interfiram na sua qualidade.

Nesse sentido, as políticas públicas adotadas pelos Estados quanto à gestão dos recursos hídricos e sua disponibilidade para uso, em si, têm forte desdobramento nas discussões em âmbito global, principalmente em relação à maneira como se pretende identificar um sentido comum à manutenção da vida humana.

Um ponto importante sobre isso são os meios de conformação da ordem jurídica global e a reflexão sobre a transnacionalização das atividades público-privadas no que tange ao uso e à gestão desses recursos. Pensando sobre a necessidade de se criar mecanismos de governança que sejam não só transparentes, mas também participativos e capazes de se proporcionar uma gestão adequada, é que se ponderou:

[...] defende-se a necessidade de se implementar uma governança corporativa regulatória (dita também simplesmente governança regulatória) em âmbito não apenas nacional (e não somente episódico-setorial, como se verifica), mas também internacional, de forma consensual com as sociedades que compõem o processo de integração, incorporando técnicas de governança corporativa na regulação de forma articulada, a significar uma governança corporativa regulatória publicizada multidimensional nas relações integracionistas de caráter global e regional (CALDAS, 2016, p. 103).

Por tais motivos, quando se discute nacionalmente questões referentes aos usos dos recursos naturais e de como eles devem ser geridos (pelo setor público, pelo privado, pelas comunidades etc.), o necessário entendimento há que ser aquele que procura, para além de uma ideia atomizada de soberania nacional, estabelecer um diálogo imediato entre as diretrizes nacionais com a dimensão internacional de regulação dos usos da natureza.

Refletindo sobre esse debate amplo e complexo é que ora propõe-se, de forma sucinta, a análise de dois casos referentes ao uso da água, tanto na Espanha quanto na Itália, trazendo à baila a importância de seus mecanismos, maxime quando concebidos em uma dimensão interdependente entre o global, o regional e o nacional. 


\subsection{A ESPANHA E A PARTICIPAÇÃO COMUNITÁRIA}

Na história recente das políticas públicas relacionadas à gestão da água na Espanha, pode ser observado um incentivo à privatização ocorrido entre 1985 e 2000. Posteriormente, a orientação dessa tendência foi alterada, predominantemente entre 2001 e 2008, quando a privatização dos serviços públicos passou a ser questionada por setores da sociedade que defendiam a atuação e gestão do Estado.

Nesse sentido, como explica Magalhães Junior (2017), surgiram alternativas com a gestão municipal da água em associações de municípios, chamadas de "mancomunidades". Porém, após a crise internacional de 2008, a tendência do retorno à privatização voltou a ser a principal opção adotada pelo Estado na gestão da água na Espanha.

Apesar de a privatização da água ser um importante tema de debate mundial, nota-se, na Espanha, uma ausência de sistemas de regulação desse processo. Foi esse cenário que levou a sociedade civil, naquele país, a se movimentar e exigir maior atenção do Estado no que tange à regulamentação dos usos da água. Conforme explica Magalhães Junior (2017, p. 159-160),

Neste sentido, em 21 de abril de 2016, um conjunto de entidades da sociedade civil apresentou, no Congreso de los Diputados, uma lista de prioridades de gestão da água na qual está presente a solicitação de incorporar explicitamente a garantia do direito humano à água e ao saneamento na legislação espanhola, especificamente na Lei da Água. As entidades alegaram que este princípio não está garantido de modo claro nos documentos legais, o que agrava a situação de acesso aos serviços básicos de certos setores sociais desfavorecidos e mais vulneráveis economicamente. $\mathrm{O}$ documento apresentado propõe que todos os cidadãos tenham a garantia de uma vida digna com o auxilio do atendimento pelos serviços essenciais, sem riscos de cortes pelo não pagamento por parte dos setores desfavorecidos. Outras criticas aos serviços privados são a menor transparência com relação à gestão pública, o não fomento à participação cidadã nos processos de gestão e os custos mais elevados (cerca de 25\%) em relação aos serviços geridos pelo poder público. A Fundación Nueva Cultura del Agua defende os processos de remunicipalização dos serviços a partir de maior vontade política e de maior apoio entre as instâncias de poder público, particularmente entidades supramunicipais, para facilitar a transição.

A menção à inclusão "explicitamente" como garantia de que a água seja classificada como um Direito Humano na Espanha significa que sua gestão deve ser pautada por valores que transcendem o seu uso comercial, independentemente de sua gestão ocorrer por órgão estatal, privado ou até mesmo por uma parceria público-privada. O que está em jogo é um avanço dos critérios que pautem a exploração da água, sendo que a vantagem de uma gestão pública do recurso é vista quanto à "[...] incorporação de critérios de eficácia, eficiência e transparência, entre outros condicionantes.” (MAGALHÃES JUNIOR, 2017, p. 160).

Outro aspecto importante gerado com a recente discussão sobre gestão da água e a implantação de ações sobre sua exploração e uso foi a reafirmação de identidades das comunidades locais. A questão da água colocou a Espanha diante do desafio da (re)construção das 
diferentes identidades regionais, identificadas naquelas que são denominadas de comunidades autónomas. $\mathrm{O}$ uso da água, que estava anteriormente nas mãos de um modelo e projeto centralizador, transformou-se, como foi dito, num processo agora compartilhado entre o Estado e as diversas esferas regionais: políticas, econômicas e sociais.

Neste sentido, o discurso estatal da manutenção e reforço da 'identidade espanhola', em que um dos instrumentos era as políticas hidráulicas tradicionais de alocação e distribuição de água, se viu confrontado por múltiplos e fragmentados interesses, objetivos e identidades regionais. No contexto da diversidade regional, a água não é vista unicamente na perspectiva do desenvolvimento, mas também como um patrimônio territorial carregado de significados que não estão limitados à concepção monetária e econômica (MAGALHÃES JUNIOR, 2017, p. 231).

A questão é complexa. Apesar de levantar a possibilidade de se repensar a integração a partir da participação ativa das comunidades locais num processo nacional de gestão de um recurso, muitas vezes, as diferenças se ampliam quando as dimensões culturais, econômicas (interesses monetários e de empresas privadas) e políticas se sobrepõem.

O conceito de 'pegada hídrica' facilita compreender que em grande parte dos países mediterrâneos, as políticas da água estão condicionadas diretamente pelas políticas agrícolas. Portanto, como vem sendo enfatizado na Espanha, as políticas da água não deveriam ser concebidas e aplicadas somente no âmbito institucional do Ministério do Meio Ambiente e dos organismos de bacia. Há uma difícil e complexa necessidade de integração setorial e institucional que viabilize a conexão entre as decisões nos diversos campos territoriais de gestão ambiental e de definição das políticas econômicas (MAGALHÃES JUNIOR, 2017, p. 300).

A grande paleta da diversidade de políticas tradicionais locais encontra, muitas vezes, dificuldades de se aliar a um projeto nacional. E, para além do âmbito nacional, outros problemas surgem; por exemplo, tem-se o caso da Catalunha.

Nessa região, o discurso de integração e solidariedade nacional vai de encontro às suas aspirações separatistas, chocando-se, portanto, com um projeto de integração nacional na gestão da água.

Porém, é interessante notar que, nesse caso, o discurso passa a apoiar uma espécie de "solidariedade europeia", fazendo referência à necessidade de cooperação internacional no uso de um bem elevado à condição de direito humano. Observa-se que, em tal situação, o local pode não se identificar totalmente com o âmbito nacional, mas pode recriar um laço de solidariedade em âmbito internacional.

De qualquer forma, as necessidades impostas deixaram claro, para a definição das políticas de gestão transparente das águas na Espanha, que o estabelecimento de um sistema participativo é fundamental para se efetivar o desenvolvimento de mecanismos que unam um direito humano à viabilidade econômica e sustentável.

Portanto, a modernização da gestão da água na Espanha não pode passar ao largo de questões de fundo que afetam as sociedades em diferentes escalas 
espaço-temporais: a gestão da água, antes de ser um processo de políticas de águas, é um processo de políticas territoriais e de modelo de desenvolvimento. Estes modelos devem contemplar estratégias de integração entre as dimensões ecológica, econômica e social, buscar a integração da gestão da água no contexto das políticas territoriais e definir estratégias de utilização de recursos associadas à proteção da qualidade ambiental. Somente a gestão da água com viés territorial, e não setorial, pode conseguir abordar as diferentes dimensões envolvi- das na configuração das pressões humanas nos ecossistemas aquáticos (MAGALHÃES JUNIOR, 2017, p. 230).

A necessidade de reorientação do Estado, em suas diferentes formas de atuação, e a importante ação do Poder Público nas políticas de gestão da água na Espanha, a seu turno, vêm capitaneando as principais pautas de discussão, especificamente em relação aos serviços de águas e saneamento.

Apesar de, como no Brasil quanto aos municípios, as localidades espanholas terem a competência constitucional para realizarem a organização dos serviços sobre a água, a grande parte desses serviços é transferida para a administração privada, a qual acaba realizando também, total ou parcialmente, a execução, sendo certo que "As causas desta transferência são variadas e vão desde a incapacidade técnica e institucional do poder público local até a inércia e falta de interesse político." (MAGALHÃES JUNIOR, 2017, p. 301).

Pode-se acrescentar que as localidades têm seus compromissos vinculados, muitas vezes, apenas aos quatro anos de duração dos mandatos de seus quadros eletivos de governo, o que acarreta o abandono de preocupações mais amplas, como se tem em relação à eficiência (e do planejamento no longo prazo), ao envolvimento da participação popular e às questões ambientais, as quais, acabam, na maioria das vezes, sendo relegadas a segundo plano.

\subsection{A ITÁlIA E O BEM COMUM}

No caso da Itália, significativo foi o movimento ocorrido em Nápoles, que culminou com a remunicipalização da gestão da água em 2011. Esse movimento começou em 2003, quando um grupo de acadêmicos do Ministério da Economia e Finanças apresentou o resultado de um trabalho desenvolvido para a construção de uma Conta Patrimonial das Administrações Públicas.

Surgiu, naquele momento, a compreensão de que era um objetivo imediato avaliar os modos de privatização de alguns grupos de bens e contar com novas ideias sobre o tema. Foi, então, proposto que os novos trabalhos deveriam estar mais em sintonia com as diretrizes de sustentabilidade mundial e, também, conectados com uma gestão que integrasse o interesse geral das comunidades envolvidas.

A iniciativa, numa primeira fase, foi bem recebida pelo então Ministro da Economia e Finanças. No entanto, com a mudança de cargo ocorrida em julho de 2005, não se deu continuidade ao projeto. Na sequência, em junho de 2006, foi apresentado um workshop realizado na Academia Nacional de Lincei, intitulado "Patrimônio Público, Propriedade Pública e Propriedade Privada”. 
Naquele momento, um importante grupo de estudiosos, compostos por juristas e economistas, chegou à conclusão de que era necessário continuar o trabalho com relação aos bens públicos por meio de duas iniciativas realizadas em conjunto e conectadas: a primeira dizia respeito a uma revisão do quadro legal dos bens públicos contidos no Código Civil; a segunda constituía-se na continuação do trabalho iniciado com o projeto experimental do Balanço das Administrações Públicas para fortalecer o contexto de conhecimento dos bens patrimoniais.

O trabalho da Comissão começou em 4 de julho de 2007 e foi presidido por Stefano Rodotà, o qual estabeleceu, dentro do Ministério da Justiça italiano e por meio de Decreto Ministerial datado de 21 de junho de 2007, a elaboração de um projeto de lei que permitia a modificação das regras no Código Civil acerca dos bens públicos (ITÁLIA, 2007). Como observam Dardot e Laval, esse processo de lutas sociais pela gestão da água levou mais de uma década, culminando em 2011

A batalha da água na Itália partiu de comitês locais para 'recuperar os bens comuns', segundo dizia a palavra de ordem que se popularizou após a mobilização 'antiglobalizzazione' em Gênova, em 2001. Desde meados dos anos 2000, os comitês de Nápoles e região tiveram um papel importante na constituição da rede de comitês do Fórum dos Movimentos pela Água. Paralelamente, o governo Prodi encarregava a Comissão Rodotà de introduzir no Código Civil, na parte relativa à propriedade pública, um artigo sobre a noção de bens comuns, ao lado das noções de bens privados e bens públicos. Em 2007 e 2008, a mobilização de juristas como Alberto Lucarelli e Ugo Mattei, ao lado de Stefano Rodatà, permitiu que a questão do comum se colocasse no centro do debate público e ajudou o movimento a exigir um referendo em 2011, após a coleta de milhões de assinaturas (DARDOT; LAVAL, 2017, p. 555).

Esse processo de conquista da participação da sociedade civil italiana sobre (parte) (d) o controle e gestão da água pode ser observado também, de uma maneira geral e nesse mesmo período, com pequenas diferenças e formas de especificidade, nos desdobramentos políticos e legislativos ocorridos na Espanha - conforme o caso acima apresentado - e, também, na França, tendo sido influenciado sobremaneira pelo referendum ocorrido com resultado a prol da remunicipalização da gestão da água na Itália, refletindo, na sequência, por entre as localidades.

Um exemplo notável e recente é Napoli, na Itália, onde a prefeitura decidiu remunicipalizar os serviços de água como uma resposta ao referendo italiano, realizado em junho de 2011, sobre a privatização da água, em que 96\% dos eleitores optaram por derrubar as leis que facilitavam a privatização da água no país. Essa é uma das expressões mais significativas de apoio público para a remunicipalização dos serviços de água (HOEDEMAN; KISHIMOTO; PIGEON, 2012, p. 106).

O tema, em Nápoles, desdobrou-se para um debate amplo, envolvendo diversas camadas da sociedade, referindo-se à água de acordo com uma concepção de "bem comum" advinda da doutrina de Mattei (2011), o qual acompanhou de perto os trabalhos da Comissão Rodatà 
(ITÁLIA, 2007) como seu vice-presidente. Há que se recordar, outrossim, que a questão também foi abordada por Esposito (2011), que, com sua filosofia do bem comum, procurou evidenciar a centralidade e a importância do assunto.

Apontando para a nacionalização e a privatização como tópicos centrais dos projetos políticos anteriores, característicos do século XX, Esposito procura mostrar como, agora, no século XXI, uma guinada deve ser direcionada para a proteção e o gerenciamento dos recursos naturais, vistos não como um simples produto de consumo, mas como um bem comum, ou seja, a ser identificado em relação direta com as comunidades que usufruem e se relacionam diretamente com ele.

Mas, mesmo para além dos diversos livros que apresentaram o tema, pode-se dizer que a questão dos bens comuns tenha literalmente explodido em todo o mundo. Objeto de estudo de grupos de pesquisa qualificados em 2009, foi a ocasião da atribuição do Nobel ao economista norte-americano Elinor Ostrom, autor de um livro, Governing the Commons, a ela dedicado. No centro da batalha pela defesa da terra em Chiapas e no Brasil e daquela, também vencedora, pela água pública em Paris, tornou-se a ponta de lança da campanha eleitoral de De Magistris em Nápoles, que, recém eleito prefeito, confiou o primeiro departamento dos bens comuns ao constitucionalista Alberto Lucarelli. Todas as manifestações que acompanharam as cúpulas dos Grandes de Terra sobre a economia e o clima - de Seattle a Cancún - repropuseram, com força crescente, o motivo do "comum". "O trabalho é um bem comum" foi o slogan de um recente protesto sindical na Itália. E o que mais pedem os indignados em Atenas, Tel Aviv, Madri e Nova York senão o respeito pelos bens não disponíveis, ou mesmo a diminuição da dívida soberana dos vários países? (ESPOSITO, 2011, online).

Nesse sentido, tais temas e modelos de gestão participativa dos recursos hídricos, com transparência e integração junto aos meios de governança internacional, em si, passam a ser facetas de um mesmo problema.

A questão passa a se desdobrar para outros importantes setores da política, pois, como demonstram Dardot e Laval (2017), o efeito desses projetos que transferem poderes de gestão de recursos naturais para as comunidades locais acaba por subtrair certos domínios estratégicos do mercado e impedir a continuidade de sistemas políticos, por vezes baseados na corrupção ou cooptação dos gestores públicos.

Segundo os autores, diminuem-se os privilégios não só das privatizações feitas pelas multinacionais, mas, também, trata-se de diminuir as fundações de um modelo político que "[...] se alimenta da propriedade pública pela distribuição de cargos, pelo clientelismo e pelo nepotismo, quando não pelo desvio de verbas, etc." (DARDOT; LAVAL, 2017, p. 557).

É nessa direção que a crítica filosófico-sociológica compreende os bens comuns e identifica sua importância como paradigma de pacto social, isto é, como uma relação estabelecida entre as comunidades e os bens como sendo não uma relação de apropriação, segundo um modelo jurídico tradicional, mas, sim, como "[...] relações entre sujeitos que agem para tornar efetivo certo número de direitos ao uso das coisas, e não às coisas em si" (DARDOT; LAVAL, 2017, p. 556). ${ }^{13}$

13 No mesmo sentido, sobre o conceito de bens comuns, consoante anteriormente tratado. 


\section{CONCLUSÃO}

Tem-se que a ética no discurso habermasiana e apelsiana, estruturada em torno de uma razão comunicativa, busca a identificação de processos de participação que sejam capaz de efetivamente envolver os concernidos, de forma democrática e direta, na discussão dos conflitos de seus interesses, o que, em si, implica a superação de um paradigma democrático meramente representativo e segmentador nos Estados, a prol de uma óptica global e transnacional concertada.

A aplicação dessa ética discursiva, alicerçada na razão comunicativa, ao estudo do complexo sistema de recursos hídricos para a criação de uma global governance voltada para si, demonstra a necessidade de utilização da referida óptica global e transnacional concertada, isto é, sem fronteiras e com a soberania permanente sobre os recursos hídricos dos Estados sendo obtemperada para atender a uma racionalidade ambiental apta a garantir o direito humano fundamental de acesso a água potável e saneamento.

Resta importante aperceber-se, dessa maneira, que os movimentos sociais envolvendo diferentes setores da sociedade acerca dos recursos hídricos (sendo aqui identificados em dois casos particulares, quais sejam, o da Espanha e da Itália), especialmente quando considerados como bens comuns, implicam uma reavaliação da dualidade entre a soberania do Estado e a propriedade privada, bem como entre as esferas nacional e local, e, bem ainda, entre as esferas pública e particular devidamente pactuadas, emparceiradas em um Estado com sua dimensão regional e global, em favor da construção de uma visão de tais recursos naturais sendo considerados como bens comuns.

No caso da Espanha, verifica-se que os interesses da sociedade local podem não se identificar totalmente com os havidos em âmbito nacional, mas, mesmo assim, são capazes de recriar um laço de solidariedade no nível de interesses regionais e internacionais, não obstante a existência de conflitos latentes, circunstância esta de superação de impasses dentro de uma dinâmica ética discursiva habermasiana e apelsiana que deve servir de modelo para outros Estados com questões similares.

A seu turno, a tendência de remunicipalização da gestão dos recursos hídricos na Itália, após a realização de um referendum, segundo um modelo de gestão participativa, em si, revela a adoção de uma racionalidade ambiental (em contexto de racionalidade comunicativa habermasiana e apelsiana) que toma em consideração os valores culturais presentes em sociedade, dando-lhes atenção para galgar-se uma governança regulatória dialógica efetiva e satisfatória, o que merece ser replicado em âmbito internacional e global, além de influenciar outras localidades.

Dessa forma, à luz do viés de compreensão do setor privado, é importante que se solidifique um entendimento comum para a regulação e a governança no espaço transnacional de atuação das empresas. E esta compreensão deve levar em conta, na gestão sobre o uso de recursos naturais (mais especificamente a água e seu saneamento), a necessidade de se mesclar democraticamente os princípios da dignidade humana e dos bens comuns com os 
interesses locais, nacionais e internacionais globalizados, de cunho público e/ou privado.

Conclui-se, ainda, que a introdução de uma governança regulatória globalizada, em si, tem o condão de fazer com que os diferentes sistemas jurídicos nacionais não possam vir a funcionar como uma alternativa de desvio estratégico para burlarem os deveres de observância a uma racionalidade ambiental, em malferir ao primado da dignidade humana.

Assim, a partir da categorização do direito à água segundo a filosofia do bem comum, a governança em seu desdobramento participativo torna-se imperativa para o acesso deste bem, considerado como um direito humano fundamental, inarredável da dignidade humana.

\section{REFERÊNCIAS}

ACCIOLY, Elizabeth. A proteção do meio ambiente na União Europeia. In: FARIA, Werter R. (Org.). Estudos sobre integração. Porto Alegre-RS: Livraria do Advogado Editora, 2000.v. 1. p. 69-82.

ANDREUCCI, Álvaro Gonçalves Antunes. Uma revalorização do Direito a partir de Paul Ricoeur: o justo, a responsabilidade e a sustentabilidade. In: SILVEIRA, Vladmir Oliveira da et al. (Coord.). Justiça e [o paradigma da] eficiência: celeridade processual e efetividade dos direitos - Justiça, empresa e sustentabilidade. Curitiba: Clássica, 2013. v. 3.

ANDREUCCI, Álvaro Gonçalves Antunes; CALDAS, Roberto Correia da Silva Gomes. Governança e a gestão dos recursos hídricos no plano transnacional. In: JORGE, André Guilherme Lemos et al. (Org.). Direito empresarial: estruturas e regulação. São Paulo: UNINOVE, 2018. v. 2. p. 21-38.

APEL, Karl-Otto. La ética del discurso como ética de la responsabilidad: una transformación posmetafísica de la ética de Kant. In: APEL, Karl-Otto et al. Fundamentación de la ética y filosofía de la liberación. Cerro del Agua, México: Siglo Veintiuno, 1992.

APEL, Karl-Otto. O a priori da comunidade de comunicação e os fundamentos da ética: o problema de uma fundamentação racional da ética na era da ciência. In: APEL, Karl-Otto. Estudos de moral moderna. Tradução: Benno Dischinger. Petrópolis: Vozes, 1994. BECK, Ulrich. La sociedad del riesgo: hacia una nueva modernidad. Barcelona: Paidós, 1998.

BIERMANN, Frank; PATTBERG, Philipp. Global environmental governance reconsidered. Cambridge: Massachusetts Institute of Technology (MIT Press), 2012.

BIRNIE, Patricia; BOYLE, Alan; REDGWELL, Catherine. International law and the environment. 3th ed. New York: Oxford University Press, 2009.

BOSSELMANN, Klaus. O princípio da sustentabilidade: transformando direito em governança. Tradução Phillip Gil França. São Paulo: Editora Revista dos Tribunais, 2015. 


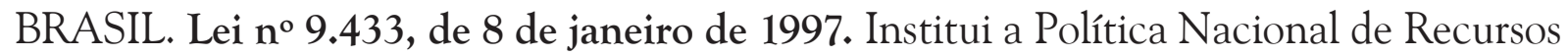
Hídricos, cria o Sistema Nacional de Gerenciamento de Recursos Hídricos, regulamenta o inciso XIX do art. 21 da Constituição Federal, e altera o art. $1^{\circ}$ da Lei no 8.001, de 13 de março de 1990, que modificou a Lei no 7.990, de 28 de dezembro de 1989. Brasília, DF: Presidência da República, 1997. Disponível em: <http://www.planalto.gov.br/ccivil_03/ LEIS/L9433.htm>. Acesso em: 17 jun. 2018.

. Comissão Nacional para os ODS. Plano de ação 2017-2019. 2017. Disponível em: <http://www.itamaraty.gov.br/images/ed_desenvsust/Plano-Acao-ComissaoNacional-ODS.pdf >. Acesso em: 17 jun. 2018.

CALDAS, Roberto Correia da Silva Gomes. Um estudo sobre a governança global e a governança europeia: convergências em prol de um sistema regulatório participativo. In: MATA DIZ, Jamile Bergamaschine; SILVA, Alice Rocha da; TEIXEIRA, Anderson Vichinkeski (Org.). Integração, Estado e governança. Pará de Minas: Virtualbooks, 2016. v. 1. p. 102-124. Disponível em: <http:/www.uit.br/mestrado/images/publicacoes/ segundo_livro_rede_24_02_2017_1.pdf>. Acesso em: 30 set. 2018.

CALDAS, Roberto Correia da Silva Gomes; MATA DIZ, Jamile Bergamaschine. Soberania permanente sobre as riquezas e os recursos naturais dos Estados: uma interpretação sistêmica do artigo 47 do Pacto Internacional de Direitos Civis e Políticos (PIDCP). Juris plenum: direito administrativo, Caxias do Sul, v. 3, n. 12, p 157-174, dez. 2016.

CALDAS, Roberto Correia da Silva Gomes; MATA DIZ, Jamile Bergamaschine. Revisitando a teoria da responsabilidade contratual do Estado sob o prisma da boa-fé objetiva.

RECHTD - Revista de estudos constitucionais, hermenêutica e teoria do direito, v. 10, n. 1, p. 5575, jan./abr. 2018. Disponível em: < http://www.revistas.unisinos.br/index.php/RECHTD/ article/view/rechtd.2018.101.05/60746257>. Acesso em: 2 out. 2018.

CALDAS, Roberto Correia da Silva Gomes; MATA DIZ, Jamile Bergamaschine; CARVALHO, Julia Vilela. Governança global e governança europeia: uma análise principiológica comparada. In: MATA DIZ, Jamile Bergamaschine; SALIBA, Aziz Tuffi; SILVA, Roberto Luiz (Org.). Europa num mundo globalizado: dilemas da coesão e do desenvolvimento sustentável. Belo Horizonte: Arraes, 2018. v. 1. p. 207-233.

CARVALHO, Sonia Aparecida de; ADOLFO, Luiz Gonzaga Silva. O direito fundamental ao saneamento básico como garantia do mínimo existencial social e ambiental. Revista brasileira de direito, Porto Alegre, v. 8, n. 2, p. 6-37, jul./dez. 2012. Disponível em: < https://seer.imed.edu.br/index.php/ revistadedireito/article/download/295/245>. Acesso em: 2 out. 2018.

CHEVALLIER, Jacques. O Estado pós-moderno. Tradução: Marçal Justen Filho. Belo Horizonte: Fórum, 2009. 
CORTE, Thaís Dalla. A (re)definição do direito à água no século XXI: perspectiva sob os enfoques da Justiça e da governança ambiental. 2015. 612 f. Dissertação (Mestrado em Direito) - Programa de Pós-Graduação em Direito da Universidade Federal de Santa Catarina, Florianópolis, 2015. Disponível em: < https://repositorio.ufsc.br/bitstream/handle/123456789/133225/333891.pdf?sequence $=1>$. Acesso em: 19 set. 2018.

COSTA, Beatriz Silva; MATA DIZ, Jamile Bergamaschine; REZENDE, Élcio Nacur. Regulación de los recursos hídricos en Brasil y la protección del agua: bien fundamental para la vida humana. In: GARCÍA LÓPEZ, Tania; TRAVIESO BELLO, Ana Cecilia (Org.). Derecho y gestión del agua. México: UBIJUS, 2015. p. 177-197.

DARDOT, Pierre; LAVAL, Christian. Comum: ensaio sobre a revolução no século XXI. São Paulo: Boitempo Ed., 2017.

ESPOSITO, Roberto. La Repubblica. Filosofia do bem comum: artigo de Roberto Esposito. Tradução Moisés Sbardelotto. Revista IHU on-line, 21 out. 2011. Disponível em: $<$ http://www.ihu.unisinos.br/noticias/502044-filosofia-do-bem-comum-artigo-de-roberto- $>$. Acesso em: 18 set. 2018.

FUNDO MONETÁRIO INTERNACIONAL (FMI). Manual de transparência fiscal. 2007. Disponível em: < https://www.imf.org/external/np/fad/trans/por/manualp.pdf>. Acesso em: 18 set. 2018.

GARCÍA LÓPEZ, Tania; MATA DIZ, Jamile Bergamaschine. Retos jurídicos tras la inclusión del derecho humano al agua en la Constitución mexicana. Revista de direito da cidade, n. 4, v. 7, p. 1.690-1.707, 2015.

GOMES, Wilson; MAIA, Rousiley C. M. [Celi Moreira]. Comunicação e democracia: problemas e perspectivas. São Paulo: Paulus, 2008.

GOMES, Wilson. A ética do discurso e a comunicação mediada e editada pelos mass media. In: HERRERO, F.; NIQUET, M. (Ed.). Ética do discurso: novos desenvolvimentos e aplicações. São Paulo: [s.n.], 2002. p. 339-359.

GONÇALVES, Alcindo; COSTA, José Augusto F. Governança global e regimes internacionais. São Paulo: Almedina, 2011.

HABERMAS, Jürgen. Direito e democracia: entre facticidade e validade. Tradução: Flávio Beno Siebeneichler. Rio de Janeiro: Tempo Brasileiro, 1997a. v. 1.

. Direito e democracia: entre facticidade e validade. Tradução: Flávio Beno Siebeneichler. Rio de Janeiro: Tempo Brasileiro, 1997b. v. 2.

. Consciência moral e agir comunicativo. Tradução: Guido A. de Almeida. Rio de Janeiro: Tempo Brasileiro, 1989. 
. Notas programáticas para a fundamentação de uma ética do discurso. In: Consciência moral e agir comunicativo. Tradução: Guido A. de Almeida. Rio de Janeiro: Tempo Brasileiro, 2003.

HELLER, Léo. Direitos humanos devem orientar políticas de água e saneamento, diz relator da ONU. mar. 2018. Disponível em: <https://nacoesunidas.org/direitos-humanos-devem-orientar-politicas-de-agua-e-saneamento-diz-relator-da-onu//>. Acesso em: 17 jun. 2018. HOEDEMAN, Olivier; KISHIMOTO, Satoko; PIGEON, Martin. Looking to the future: what next for remunicipalisation? In: PIGEON, Martin et al. (Ed.). Remunicipalisation: putting water back into public hands. Amsterdã: Transnational Institute, 2012. p. 106-112. Disponível em: < https://idl-bnc-idrc.dspacedirect.org/bitstream/handle/10625/49061/IDL-49061.pdf?sequence=1>. Acesso em: 17 jun. 2018.

ITÁLIA. Ministero dela Giustizia. Commissione Rodotà: per la modifica delle norme del codice civile in materia di beni pubblici - Relazione. Roma, 14 giugno 2007, s/n. Disponível em: <https://www.giustizia.it/giustizia/it/mg_1_12_1.wp?previsiousPage=mg_1_12\&c ontentId=SPS47617 $>$. Acesso em: 18 set. 2018.

IULIANELLI, Jorge Atilio Silva. Ética do discurso, direitos humanos e democracia: cidadania universal contra o mercado total. Síntese - Revista de Filosofia, Belo Horizonte, v. 30, n. 96, p. 13-38, 2003.

LEFF, Enrique. Epistemologia ambiental. Tradução: Sandra Valenzuela. 5. ed. São Paulo: Cortez Editora, 2002.

MAGALHÃES JUNIOR, Antônio Pereira. A nova cultura de gestão da água no século XXI: lições da experiência espanhola. [livro eletrônico]. São Paulo: Blucher, 2017. Disponível em: <http://pdf.blucher.com.br.s3-sa-east-1.amazonaws.com/openaccess/9788580392555/00.pdf > . Acesso em: 30 set. 2018.

MATTEI, Ugo. Beni comuni: un manifesto. Roma: Editori Laterza, 2011.

NACIONES UNIDAS. ACNUDH - Alto Comisionado de las Naciones Unidas para los Derechos Humanos. El derecho al água: folleto informativo no 35. 2011. Disponível em: $<$ http:// www.ohchr.org/Documents/Publications/FactSheet35sp.pdf>. Acesso em: 2 out. 2018.

ORGANIZAÇÃO DAS NAÇÕES UNIDAS (ONU). Relatório da Conferência das Nações Unidas sobre a Água. (Mar del Plata, 14-25 de março de 1977). Primeira Parte. Cap. I. Resolução II, 1977.

. Programa das Nações Unidas para o Desenvolvimento- PNUD. Relatório de Desenvolvimento Humano - RDH. 2006. Disponível em: <www.portalodm.com.br/.../1/ relatorio-de-desenvolvimento-humano---brasil-2006.pdf>. Acesso em: 16 set. 2010.

. Agenda 2030. 2015. Disponível em: <https://nacoesunidas. org/pos2015/agenda2030/>. Acesso em: 17 jun. 2018. 
PUY MUÑOZ, Francisco. Derechos humanos 1: derechos económicos, sociales y culturales. Santiago de Compostela: Imp. Paredes, 1983.

RICHMOND, Oliver P. Para além da paz liberal? Respostas ao "retrocesso". Tradução Victor Coutinho Lages. Contexto Internacional, v. 32, n. 2, p. 297-332, jul./dez. 2010. Disponível em: <http://contextointernacional.iri.puc-rio.br/media/v32n2a02.pdf $>$. Acesso em: 17 jun. 2018.

SARLET, Ingo Wolfgang; FENSTERSEIFER, Tiago. Direito constitucional ambiental: estudos sobre a constituição, os direitos fundamentais e a proteção do ambiente. São Paulo: Revista dos Tribunais, 2011.

SILVA, Geraldo Eulálio do Nascimento e. Simpósio de Foz de Iguaçu sobre a Bacia do Prata. In: CASELLA, Paulo Borba; VASCONCELOS, Raphael Carvalho de; XAVIER JUNIOR, Ely Caetano (Org.). Direito ambiental: o legado de Geraldo Eulálio do Nascimento e Silva. Brasília: FUNAG, 2017a. p. 315-318.

SILVA, Geraldo Eulálio do Nascimento e. Soberania e ambiente. In: CASELLA, Paulo Borba; VASCONCELOS, Raphael Carvalho de; XAVIER JUNIOR, Ely Caetano (Org.). Direito ambiental: o legado de Geraldo Eulálio do Nascimento e Silva. Brasília: FUNAG, 2017b. p. 39-43.

SILVA, Geraldo Eulálio do Nascimento e. Meio ambiente e desenvolvimento. In: CASELLA, Paulo Borba; VASCONCELOS, Raphael Carvalho de; XAVIER JUNIOR, Ely Caetano (Org.). Direito ambiental: o legado de Geraldo Eulálio do Nascimento e Silva. Brasília: FUNAG, 2017c. p. 35-38.

TEIXEIRA, Anderson Vichinkeski; RADKE, Rafael Wagner. Habermas e a tentativa procedimental de superação da discricionariedade judicial. Revista Brasileira de Estudos Políticos, Belo Horizonte, n. 115, p. 81-108, jul./dez. 2017.

TRINDADE, Antônio Augusto Cançado. A proteção internacional dos direitos humanos no limiar do novo século e as perspectivas brasileiras. In: FONSECA JÚNIOR, Gélson; CASTRO, Sérgio Henrique Nabuco de (Org.).Temas de política externa brasileira II. 2. ed. Brasília: FUNAG - Fundação Alexandre de Gusmão; São Paulo: Paz e Terra, 1994. v. 1. VARGAS, Éverton Vieira. Água e relações internacionais. Revista brasileira de política internacional, Brasília, v. 43, n. 1, p. 178-182, jun. 2000. Disponível em: <http://www. scielo.br/scielo.php?script $=$ sci_arttext\&pid $=$ S0034-732920000000100010\&lng $=$ en $\& n r m$ $=$ iso $>$. Acesso em: 2 out. 2018.

WEERAMANTRY, Christopher Gregory. Case concerning the Gabikovo-Nagymaros project (Hungary/Slovakia): separate opinion. ICJ Reports (September 25), 1997, reprinted in 37 ILM, 1998. Disponível em: <https://www.icj-cij.org/files/case-related/92/09219970925-JUD-01-03-EN.pdf>. Acesso em: 2 out. 2018. 
WOLFF, Hans J.; BACHOF, Otto; STOBER, Rolf. Direito administrativo. SOUSA, Tradução: António Francisco de Sousa. Lisboa: Fundação Calouste Gulbenkian, 2006. v. 1.

WORLD BANK. Governance and development. Washington: World Bank, 1992. Disponível em: <http://documents.worldbank.org/curated/pt/604951468739447676/pdf/multi-page.pdf>. Acesso em: 16 out. 2017.

. The worldwide governance indicators (WGI) project. Washington: World Bank, 2011. Disponível em: < http://info.worldbank.org/governance/wgi/\#home>. Acesso em: 16 out. 2017.

ZORZI, Lorenzo; TURATTI, Luciana; MAZZARINO, Jane Márcia. O direito humano de acesso à água potável: uma análise continental baseada nos Fóruns Mundiais da Água. Revista ambiente e agua, v. 11, n. 4, p. 954-971, 2016. Disponível em: <http:// dx.doi.org/10.4136/ambi-agua.1861 >. Acesso em: 30 set. 2018. 